\title{
Ecological engineering in a new town development: Drainage design in The Woodlands, Texas
}

\author{
Bo Yang ${ }^{\mathrm{a}, *}$, Ming-Han $\mathrm{LI}^{\mathrm{b}, 1}$ \\ a Department of Landscape Architecture and Environmental Planning, Utah State University, 4005 Old Main Hill, Logan, UT 84322-4005, USA \\ b Department of Landscape Architecture and Urban Planning, College of Architecture, Texas AEM University, College Station, TX 77843-3137, USA
}

\section{A R T I C L E I N F O}

\section{Article history:}

Received 8 October 2009

Received in revised form 12 June 2010

Accepted 2 July 2010

\section{Keywords:}

Flood control

Urban planning

Ecological planning

Watershed assessment

GIS

Stormwater management

Ian McHarg

\begin{abstract}
A B S T R A C T
This paper presents a comparative study of two different drainage designs in a 10,930-ha new town development of The Woodlands, Texas. Open surface drainage by shallow grassed swales was used in the first two subdivisions that were developed with ecological approaches. Open surface drainage mimics the natural flow regime and is regarded to mitigate development impacts on watershed. In other later subdivisions, the drainage design shifted back to a conventional stormwater drainage system, that is, curb and gutter, drop inlet, and underground piping, known to concentrate stormwater and lead to downstream flooding. The objective of this study is to compare The Woodlands' two drainage systems on their correlation with downstream floods. Two sub-watersheds within The Woodlands that used different drainage designs were compared. U.S. Geological Survey stream data from the gauge station at the outlet of each sub-watershed were used for analysis. Geographic Information System was used to quantify the development conditions. Correlation analysis was performed using measured precipitation and streamflow data. Results show that open drainage watershed generated less storm runoff than the conventional drainage watershed, given the similar impervious area in both watersheds. Furthermore, the open surface drainage watershed responded to rainfall in a way similar to its predevelopment natural forest conditions, indicating effective flood mitigation post development. In contrast, in the conventional drainage watershed, the precipitation-streamflow correlations increased enormously after development. The open drainage system presents an advantage over the conventional drainage one in mitigating flood problems in urban development.
\end{abstract}

Published by Elsevier B.V.

\section{Introduction}

Ecological engineering uses ecological sciences as the basis for design and limits human intervention in providing sustainable ecosystem design and management solutions (Mitsch and Jørgensen, 1989; Odum, 1994; Bergen et al., 2001; Matlock et al., 2001; Mitsch and Jørgensen, 2003). The same principle is embraced by ecological planning-an ecology-based approach in land use planning (McHarg, 1969; Spirn, 1984; McHarg and Steiner, 1998). Ecological planners fuse the science of ecology and the art of planning and design and mandate that planning and design facilitate ecosystems' functions. Anthropogenic uses superimposed as a result of land use planning shall produce the least amount of interference with ecosystems' natural processes (Zipperer et al., 2000; Ndubisi, 2002).

\footnotetext{
* Corresponding author. Tel.: +1 435797 0506; fax: +1 4357970503.

E-mail addresses: bo.yang@usu.edu (B. Yang), minghan@tamu.edu (M.-H. LI)

1 Tel.: +1 9798457571 .
}

As ecological engineers rely upon the self-designing ability of the ecosystems (Mitsch and Jørgensen, 1989; Odum, 1994; Todd et al., 2003), ecological planners follow nature's lead in planning and design (McHarg, 1969; Steiner, 2008). American ecological planner and landscape architect Ian McHarg developed the concept of ecological planning in his influential book Design with Nature (McHarg, 1969). In over 90 projects, McHarg used ecological science to create safe and healthy human settlements (McHarg, 2006). McHarg focuses on the natural, social, and cultural processes and sees design as an iterative process that is largely shaped by the interactions between humans and ecosystems (McHarg, 1969; McHarg and Steiner, 1998).

For over four decades, McHarg's ecological planning concept and principles have been using ecology as the basis in planning and designing projects of various scales and focuses (Steiner and Osterman, 1998; McHarg, 2006; Ndubisi, 2008). Advocated by ecological planners, a paradigm shift in stormwater management is to use the natural infiltration mechanism to treat runoff. Current literature suggests the advantage of open surface drainage best management practice (BMP) over conventional pipe drainage, 
because the former is designed to mimic the natural flow regime and is considered to facilitate stormwater infiltration, reduce peak discharge, and provide water quality treatment (Prince George's County, 1999; USEPA, 1999; Villarreal et al., 2004).

Conventional drainage method (curb and gutter, drop inlet, and underground piping) is known to concentrate stormwater and may contribute to downstream flooding (Paul and Meyer, 2001). The aim of the conventional drainage solution is for stormwater to exit as fast as possible and to minimize storage, and the system alters the flow regime and transfers stormwater faster than the natural hydrological cycle (Ferguson, 1998; Paul and Meyer, 2001; Brabec, 2009). In urban development, a conventional drainage system is typically installed along the streets and underground. Streets are placed at low elevations and function similar to detention ponds to collect stormwater in rainfall events. However, this drainage system is vulnerable when urban development exceeds its relatively limited storage capacity (Ellis and Marsalek, 1996). In addition, stagnant water on roads that is generated during intense rainfalls creates safety problems.

The U.S. Environmental Protection Agency (USEPA) (1999) suggests that open surface drainage BMP using grassed swales could replace conventional stormwater collection and conveyance systems in urban development. Open surface drainage is often designed as grassed swales pitched with a certain gradient. Grassed swales are placed at low elevations and serve as drainage channels to transport stormwater away from roadways. Roads in this situation are placed at high grounds, minimizing the safety problems.

Dry swale and wet swale are two types of grassed swales that are currently in use. The trapezoidal shape and meandering path increase the storage volume and provide a less efficient system than the channelized pipe system. Similar to the dry swale, wet swale uses natural vegetation growth to control stormwater quantity and quality (Prince George's County, 1999). If specifically designed, wet swale functions similar to a bioretention basin. A bioretention swale installed in a conventional residential road in Seattle, Washington, reported a $97 \%$ runoff volume deduction compared with the preconstruction runoff volume (Horner et al., 2002). In addition, vegetated filter strips (VFSs) installed at the top of the grassed swale channel banks help reduce and treat sheet flows (USEPA, 1999). Runoff reduction due to the use of VFSs varies between $6 \%$ (Chaubey et al., 1994) and 89\% (Schmitt et al., 1999). Finally, Villarreal et al. (2004) suggest the benefits of using a combination of BMPs in developing the open drainage system. The synergic effect of BMPs is better than one BMP, and the location of BMP is an important design consideration.
Although open surface drainage may provide an alternative to conventional underground drainage in light of the rising flooding problems, very few subdivisions have implemented open surface drainage at a large scale. One of the pioneers in the use of open drainage systems is The Woodlands, Texas, a 10,930-ha new town developed using McHarg's ecological planning concept in the 1970s (WMRT, 1973a; McHarg and Sutton, 1975; Kim and Ellis, 2009). McHarg's environmental plan used open surface drainage to maintain the site's natural hydrologic balance (WMRT, 1973b). Further, the surface drainage channels were located where highly permeable soils were present (WMRT, 1973b, 1973c, 1974).

McHarg coined the term "ecological plumbing" to represent this open drainage solution (McHarg and Sutton, 1975). The Woodlands was a multidisciplinary project that encompassed planning, ecology, hydrology, meteorology, limnology, plant ecology, etc. (WMRT, 1973a). In this new town development, McHarg's approach was implemented from regional-scale planning to sitescale design (McHarg and Sutton, 1975; McHarg and Steiner, 1998). The Woodlands development provides an example that bridged the gap between theories of ecology and subdivision planning practices, and it contributes to the new discipline of ecological engineering (Gattie et al., 2003).

The Woodlands survived storms in excess of 100-year levels in 1979 and 1994 (Girling and Kellett, 2005). Despite the lack of scientific evidence, the open drainage system is regarded as an important factor in protecting the new town from flooding (Morgan and King, 1987; Galatas and Barlow, 2004). Open surface drainage was implemented in the first two suburban villages (Galatas and Barlow, 2004). However, most homeowners did not like the rustic appearance of the open drainage channels. To improve marketability, The Woodlands gradually shifted to conventional drainage practices (Gause et al., 2002; Galatas and Barlow, 2004). Fig. 1 shows different drainage systems in The Woodlands in the early and later subdivisions. After the conventional system was installed, The Woodlands was flooded in 2000 (NOAA, 2000) and again in 2008 as a result of Hurricane Ike (Madere, 2008).

The objective of this study is to compare The Woodlands' two drainage systems on their correlation with downstream floods. Previous studies of open drainage systems usually focused on site-level scale (e.g., Horner et al., 2002; Villarreal et al., 2004). Studies conducted at a larger scale have been few (Brander et al., 2004), and some studies used a modeling approach when controlled experiment samples were not available (e.g., Girling and Kellett, 2002). This study used empirical data to assess open drainage systems at a watershed scale. Moreover, this study evaluated the system effectiveness, which was considered by the USEPA (1999)
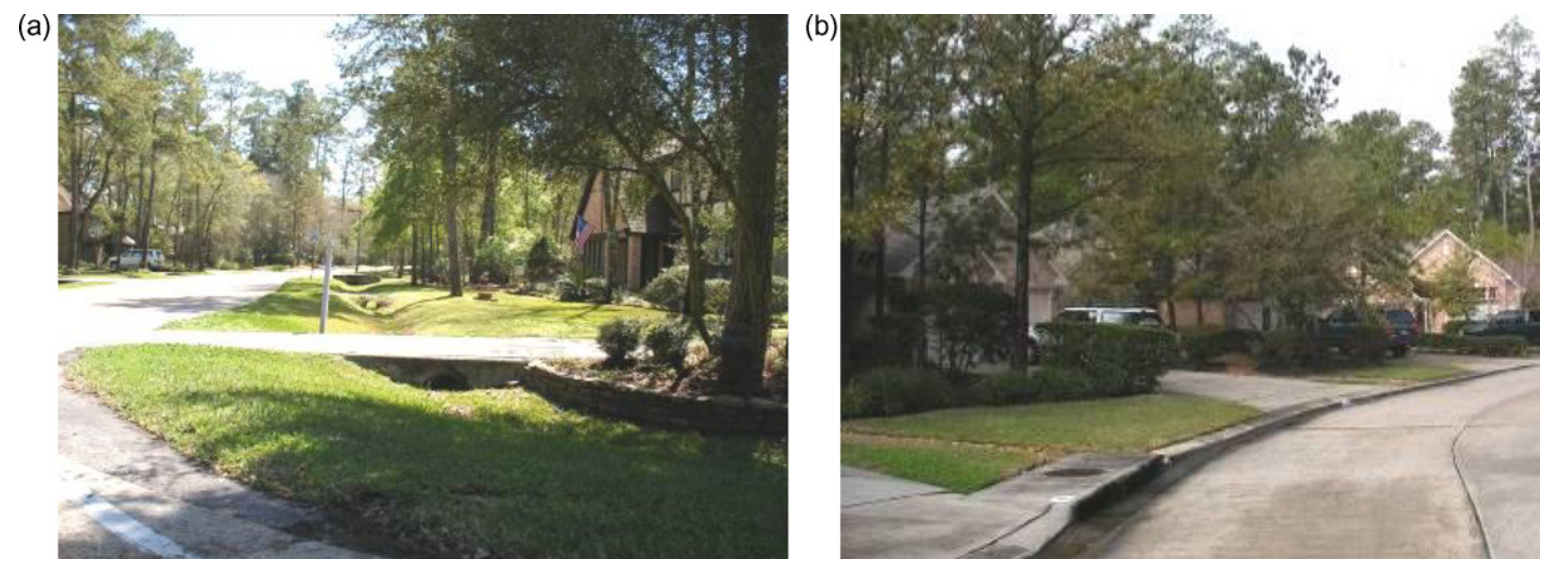

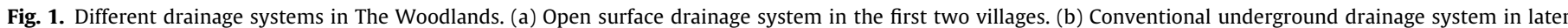
villages. 


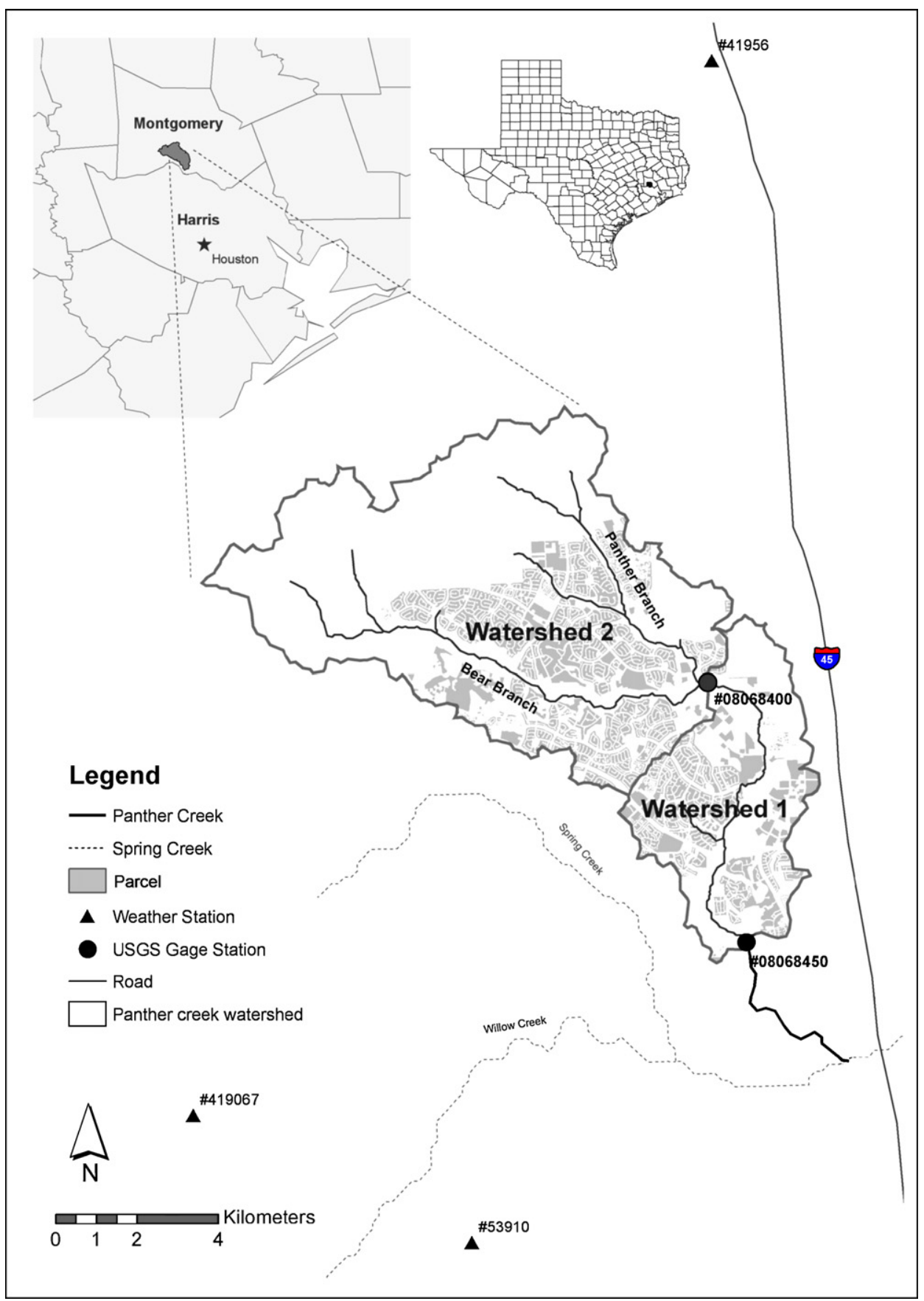

Fig. 2. Panther Creek watershed development and two sub-watersheds: Watershed \#1 and Watershed \#2.

as less desirable in intense rainfalls (e.g., Texas coastal rainfall pattern).

\section{Study site}

Fig. 2 shows the two sub-watersheds in comparison. Watershed \#1 $\left(22.3 \mathrm{~km}^{2}\right)$ and Watershed \#2 $\left(67.1 \mathrm{~km}^{2}\right)$ comprise the Panther Creek watershed-defined by the U.S. Geological Survey (USGS) gauge station \#08068450. The majority of The Woodlands is located within the Panther Creek watershed, and it lies completely within Montgomery County, Texas. U.S. Interstate Highway 45 runs parallel to The Woodlands to the east and is a major transportation corridor connecting Houston ( $48 \mathrm{~km}$ away) to the south and Dallas/Fort Worth (338 km away) to the north. In 1972, The
Woodlands development started downstream of the Panther Creek and evolved along the creek upstream.

It is important to note that Watershed \#1 does not constitute a watershed in the common definition of watershed. Watershed \#1 is the Panther Creek watershed excluding Watershed \#2. This is a working definition of Watershed \#1 for the purpose of this study. Watershed \#1 includes approximately one third of the first subdivision-Village of Grogan's Mill and the majority of the second village-Village of Panther Creek. An open drainage system was implemented in the first village and part of the second village (Kutchin, 1998; Galatas and Barlow, 2004).

Figs. 3-5 illustrate the design guidelines and built conditions of the open surface drainage. Open drainage swales were placed where soils with high infiltration capacities are available, and 


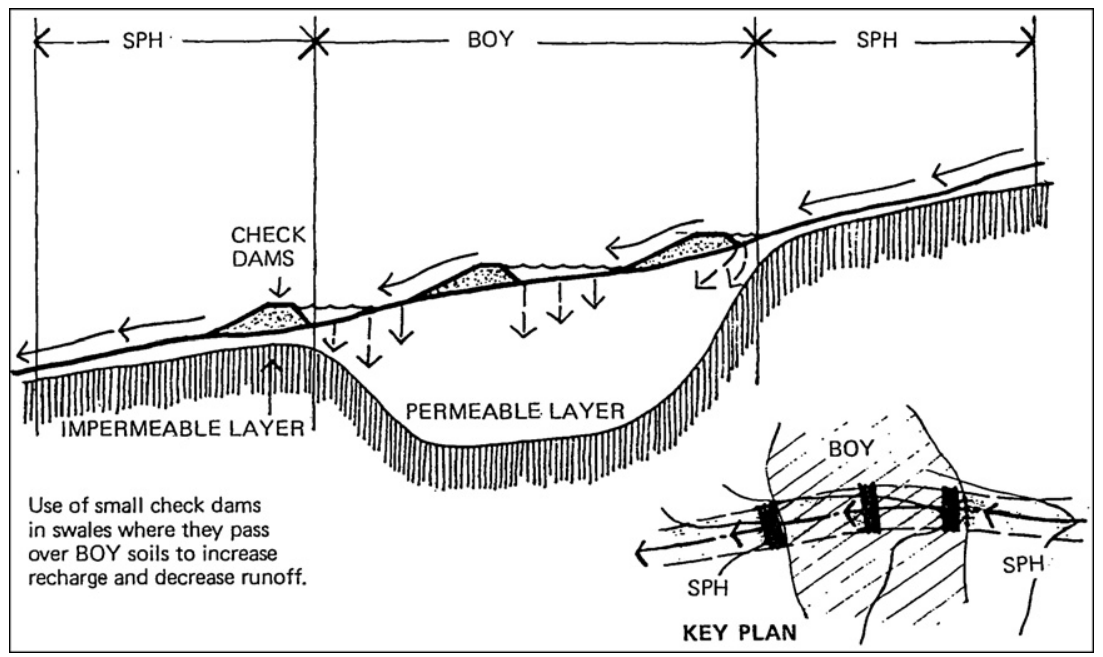

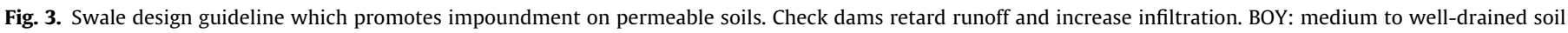
SPH (Splendora): poorly drained soil. Source: WMRT (1973c, p. 31).

check dams were used to retard runoff and promote infiltration (Figs. 3 and 4) (WMRT, 1973c). Grassed waterways were used and natural vegetated buffer zones were protected (Fig. 5) (WMRT, 1973c). After development of the first two villages, open surface drainage was still used in arterial roads and collectors but was changed to a conventional drainage system in subdivisions (Gause et al., 2002).

Watershed \#2 is defined by the USGS gauge station \#08068400. Watershed \#2 remained a pine forest when development started in Watershed \#1. Four villages-Alden Bridge, Sterling Ridge, Cochran's Crossings, and Indian Springs-are located in Water-

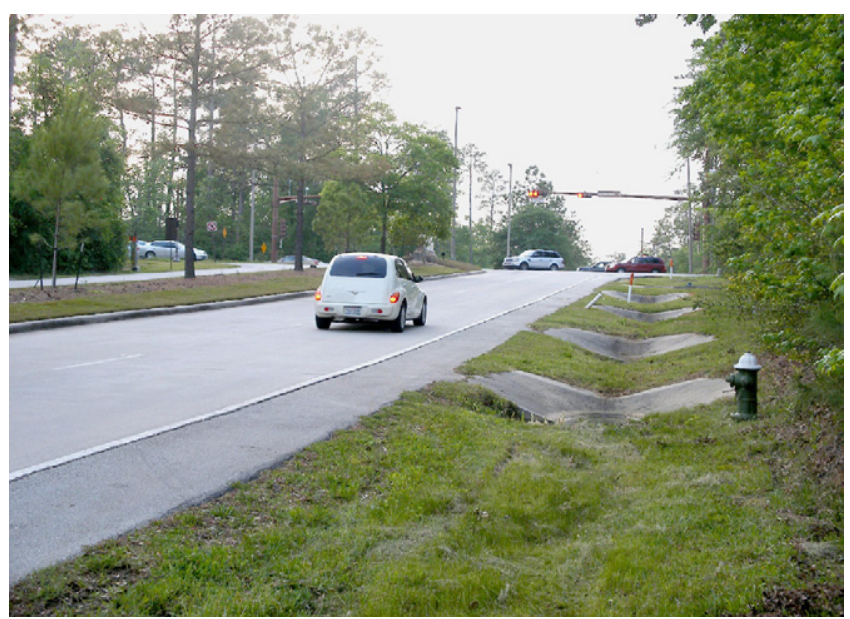

Fig. 4. Open surface drainage along collector streets. Check dams retard runoff and encourage impoundment on soils with good infiltration capacity. Also see Fig. 3. shed \#2. Conventional drainage systems were installed in those villages.

\section{Data}

Three types of data were needed for this study: parcel, streamflow and precipitation. Parcel data reflect development conditions in the watershed. Urban development introduces impervious cover that presents an important variable affecting watershed runoff. Generally, the larger the development area, the larger the impervious area and the more runoff generated (Schueler, 1994; Arnold and Gibbons, 1996; Booth and Jackson, 1997). Table 1 summarizes data source, modification, and analysis. The detailed procedure of data analysis is described in the following section.

\subsection{Impervious area}

The Woodlands development included various types of impervious areas, including roads, building footprints, sidewalks, driveways, etc. The two primary types were residential buildings and roads. Residential development conditions could be reflected by parcel data, which were obtained from Montgomery County Appraisal District. However, parcel data do not provide the conditions of sidewalks and driveways. Estimation was done for these impervious areas and the procedure is introduced in Section 5.

Road information was obtained from the Texas Natural Resources Information System (TNRIS). There were several sources for road information, such as TNRIS and the Texas Transportation Institute (TTI). However, none of them provided the year of road construction. For a particular road, parcels adjacent to it were identified and sorted by year of construction. Then the earliest year was assigned to that road, based on the assumption that the road

Table 1

Data source, modification and analysis.

\begin{tabular}{|c|c|c|}
\hline Data & Source & Explanation/modification/analysis \\
\hline Parcel & Montgomery County Appraisal District & Provide annual development conditions \\
\hline Road & TNRIS websitehttp://www.tnris.state.tx.us/ & Provide road length, but no information of year built \\
\hline \multirow[t]{2}{*}{ Streamflow } & USGS website & Flow $_{\text {watershed\#1 }}=$ Flow $_{\# 08068450}-$ Flow $_{\# 08068400}$ \\
\hline & http://www.usgs.gov/ & $\begin{array}{l}\text { Flow }_{\text {watershed } \# 2}=\text { Flow } \# 08068400 \\
\text { Analysis } 1 . \text { Include lake detention effect }\end{array}$ \\
\hline Precipitation & NCDC website http://www.ncdc.noaa.gov & $\begin{array}{l}\text { Analysis 2. Exclude lake detention effect } \\
\text { COOPID \#411956 substitutes for WBANID \#53910 in 1975-1976 }\end{array}$ \\
\hline
\end{tabular}




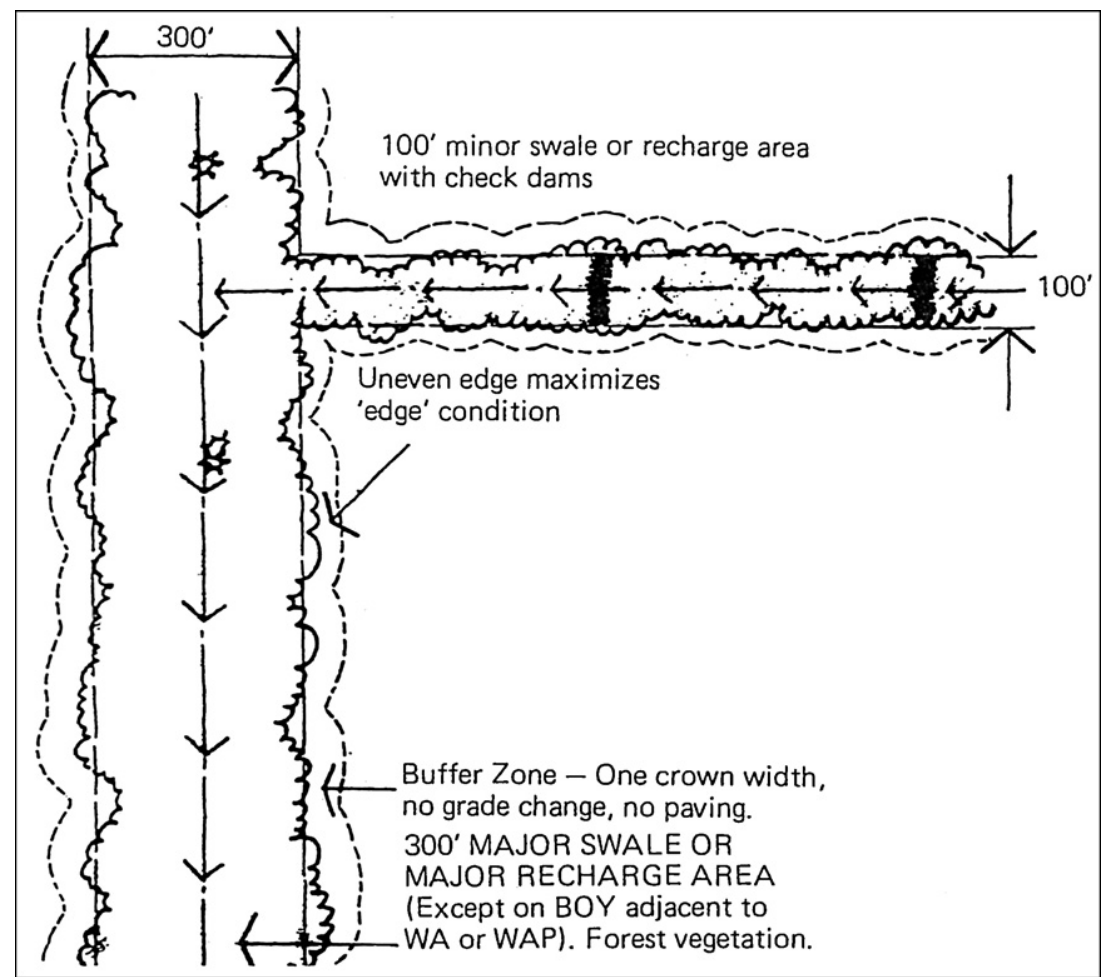

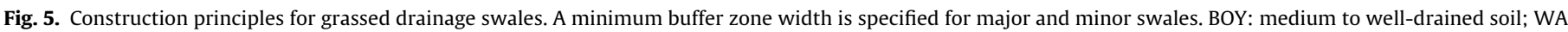
(Waller): poorly drained soil; WAP (Waller ponded): very poorly drained soil. Source: WMRT (1973c, p. 19).

has to be built for the parcel to be developed (Rogers and DeFee, 2005).

\subsection{Streamflow}

Streamflow data at USGS gauge stations \#08068400 and \#08068450 were downloaded from the USGS website. Due to data availability, data for water years 1975-1976 represented the early phases of development and data for water years 2000-2002 represented the later phases. According to the USGS definition, a water year is from October of the preceding year to September of the current year (i.e., water year $1975=10 / 01 / 1974$ to 9/30/1975). For both watersheds, water years 1975-1976 and 2000-2002 were examined.

\subsection{Precipitation}

Historical precipitation data that are coincident with flow data were obtained from the National Climatic Data Center website (NCDC). The Thiessen polygon method was used to estimate precipitation for both watersheds. Three weather stations (COOPID \#411956, COOPIN \#419067, and WBANID \#53910) were identified according to the Thiessen method. The area weighted percentage of each station was used to calculate the composite precipitation value for each rainfall event.

Because station WBANID \#53910 did not have data records for water years 1975-1976, data from the nearest station, COOPID \#419067 (less than $7 \mathrm{~km}$ away), were used as a substitute. For both watersheds, if one station had data missing for a sample day, that day was excluded from analysis. No attempt was made to estimate the missing data.

\section{Data treatment}

\subsection{Streamflow}

As aforementioned, Watershed \#1 is not a typical watershed in the hydrologic definition. Watershed \#1 is a sub-watershed located at the lower portion of the watershed defined by gauge \#08068450 (see Fig. 2). With the assumption that the flow measured at the upstream gauge \#08068400 incurred no loss in moving downstream, streamflow contributed solely from Watershed \#1 can be calculated by subtracting flow at the downstream gauge \#08068450 from flow at the upstream gauge \#08068400:

$Q_{1}=Q_{p c}-Q_{2}$

where $Q_{1}$ is the Watershed \#1 daily mean streamflow $\left(\mathrm{m}^{3} \mathrm{~s}^{-1}\right) ; Q_{p c}$ is the daily mean streamflow at gauge \#08068450 (Panther Creek watershed outlet) $\left(\mathrm{m}^{3} \mathrm{~s}^{-1}\right)$; and $Q_{2}$ is the daily mean streamflow at gauge \#08068400 (Watershed \#2 outlet) $\left(\mathrm{m}^{3} \mathrm{~s}^{-1}\right)$.

For the same day, flow at the downstream gauge \#08068450 is typically greater than flow at the upstream gauge \#08068400, a reasonable result as more surface runoff would contribute to downstream areas. Only 19 negative flow values (2.6\%; of 731 samples) in water years 1975-1976 were found and removed from analysis. However, negative flow values were much more frequent in water years 2000-2002: 87 negative values (7.9\%; of 1096) were observed. The reason for more negative values in water years 2000-2002 than 1975-1976 may be attributed to the 92-ha Woodlands Lake (built in 1985) that intercepts the stream in Watershed \#1. When the lake's water level is low after a long dry period, subsequent rainfall must refill the lake before the downstream section flows again. In this sense, the lake intercepts the flow and detains it. 
Table 2

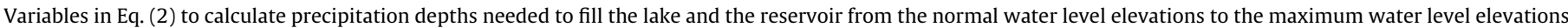
in water years 2000-2002.

\begin{tabular}{|c|c|c|c|}
\hline Variable & Value & Unit & Explanation \\
\hline \multirow[t]{2}{*}{$P$} & 45.4 (calculated) & $\mathrm{mm}$ & Precipitation depth needed to fill the lake \\
\hline & 41.8 (calculated) & $\mathrm{mm}$ & Precipitation depth needed to fill the reservoir \\
\hline \multirow[t]{2}{*}{$Q$} & 0.31 (calculated) & $\mathrm{mm}$ & Runoff volume of sub-watershed $\# 1^{a}$ \\
\hline & 0.23 (calculated) & $\mathrm{mm}$ & Runoff volume of sub-watershed \#2 $2^{\mathrm{a}}$ \\
\hline$S$ & 2.7 (calculated) & $\mathrm{mm}$ & Potential maximum watershed storage \\
\hline Curve number & 79 & NA & $\mathrm{CN}$ used for both sub-watersheds ${ }^{\mathrm{b}}$ \\
\hline \multirow[t]{2}{*}{$A_{\text {lake/reservoir }}$} & 918,030 & $\mathrm{~m}^{2}$ & Area of The Woodlands Lake \\
\hline & 205,904 & $\mathrm{~m}^{2}$ & Area of the Bear Branch Reservoir \\
\hline \multirow[t]{2}{*}{$\Delta H_{\text {lake/reservoir }}$} & 0.3 & $\mathrm{~m}$ & Elevation difference between the normal water level elevation and the \\
\hline & 0.3 & $\mathrm{~m}$ & maximum water level elevation (lake bank elevation) ${ }^{c}$ \\
\hline \multirow[t]{2}{*}{$A$} & $90,444,600$ & $\mathrm{~m}^{2}$ & Sub-watershed \#1 area \\
\hline & $26,986,500$ & $\mathrm{~m}^{2}$ & Sub-watershed \#2 area \\
\hline
\end{tabular}

a Assuming a uniform depth of runoff across the watershed.

b Using the average value of 2001 and 2005 CNs of Panther Creek watershed for approximation. $2001 \mathrm{CN}=77.6 ; 2005 \mathrm{CN}=80.4$.

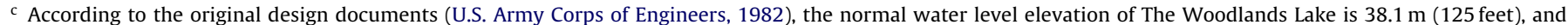

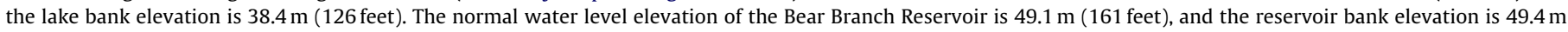
(162 feet). There is a $0.3 \mathrm{~m}$ ( 1 feet) elevation difference in both water bodies.

Two flow datasets were prepared for Watershed \#1. The first dataset included The Woodlands Lake detention effect, whereas the second dataset excluded this effect. The first dataset included all the data derived from Eq. (1) but excluded negative values. This dataset was used for water years 1975-1976 and 2000-2002. The second dataset excluded the negative values and further excluded data samples when The Woodlands Lake intercepted a significant amount of flow during its low water level periods. This set of data was only used for water years 2000-2002.

Watershed \#2 has the same stormwater detention issue as a result of the 21-ha Bear Branch Reservoir built in 1984. This reservoir should have affected the measured flow in water years 2000-2002. Similar to Watershed \#1, two flow datasets were prepared for Watershed \#2. The first dataset was used for both water-year periods, and the second dataset was used only for water years 2000-2002.

\subsection{Excluding lake/reservoir detention effect}

Since The Woodlands Lake and the Bear Branch Reservoir will intercept subsequent stream flows after dry periods, it is imperative to exclude the detention effect in order to evaluate the different drainage systems. Two methods were used to exclude such effect, described in the following subsections.

\subsubsection{Method 1}

A user-defined point at the outlet of The Woodlands Lake was used to delineate the lake contributing area-Sub-watershed \#1. Rain falling onto Sub-watershed \#1 should contribute to The Woodlands Lake. Similarly, a user-defined point at the outlet of the Bear Branch Reservoir was used to delineate the reservoir contributing area-Sub-watershed \#2.

Assuming uniform precipitation throughout the watershed (or sub-watershed), the depths to fill the lake and reservoir from the normal water level elevations to the maximum water level elevations were calculated using Eq. (2). Variables in Eq. (2) are listed in Table 2 .

$Q=\frac{(P-0.2 S)^{2}}{P+0.8 S}$

$S=\frac{1000}{C N}-10$

$Q=\frac{A_{\text {lake } / \text { reservoir }} \times \Delta H_{\text {lake } / \text { reservoir }}}{A}$
According to the original design, $\Delta H_{\text {lake/reservoir }}$ was given the value of $0.3 \mathrm{~m}$ ( $1 \mathrm{feet}$ ) in calculation. The calculated precipitation depths were $45.4 \mathrm{~mm}$ for Watershed \#1 and $41.8 \mathrm{~mm}$ for Watershed \#2. These values were used to identify sample days when the lake/reservoir was filled by rainfall. Seventeen samples were identified for Watershed \#1, and 56 for Watershed \#2. However, it was found that 15 of the total 17 samples in Watershed \#1 and 46 of the total 56 samples in Watershed \#2 have streamflow values twice as the base flow values. This result indicated that the lake and the reservoir have reached their maximum water level elevations after rainfall at the calculated depths. Method 1 thus yielded values much greater than what was needed to fill the lake and the reservoir.

\subsubsection{Method 2}

Method 2 used measured precipitation data to calculate the depths, and the results were compared with the results obtained by Method 1. In Method 2, the depths were estimated by averaging precipitation values when corresponding flow values just increased from the base flow value to greater values. Under this condition, the lake/reservoir was just filled up and no substantial additional runoff was generated by these precipitation events. Certain criteria were specified to target those precipitation samples. (1) On the first day when precipitation occurs, flow remains close to the base flow (around $0.3 \mathrm{~m}^{3} \mathrm{~s}^{-1}$ ). (2) There is no precipitation or only modest precipitation on the second day. (3) On the second day, flow becomes slightly greater than the base flow.

In total, 11 precipitation samples met the above criteria for Watershed \#1, and 16 samples for Watershed \#2. The average depths from these samples were calculated for each watershed. Finally, the average depths from Method 1 and Method 2 were used to determine the precipitation depths, and the results are presented in Table 3.

Table 3

Estimated precipitation depths to fill the lake and reservoir using two different methods.

\begin{tabular}{llll}
\hline & \multicolumn{3}{l}{ Rainfall depth (mm) } \\
\cline { 2 - 4 } & Method 1 & Method 2 & Avg. of Methods 1 and 2 \\
\hline The Woodlands Lake & 45.4 & 37.9 & 41.7 \\
Bear Branch Reservoir & 41.8 & 21.2 & 31.5 \\
\hline
\end{tabular}




\subsection{Precipitation-streamflow data pair selection}

Precipitation-streamflow data pairs were selected to assess how the watersheds responded to rainfall within different drainage systems. Following a long dry period, streamflow is usually lower than the base flow because the arid soil absorbs much rain water before excessive runoff occurs. The precipitation-streamflow relationship was further complicated after 1985, when The Woodlands Lake and the Bear Branch Reservoir stormwater detention facilities were built.

For both water-year periods, precipitation-streamflow data pairs were assessed under two different conditions. For water years 1975-1976, the first condition was the watershed status quo condition. The second condition excluded the watershed's dry periods. Similarly, for water years 2000-2002, the first condition was the status quo condition, and the second condition excluded the lake/reservoir detention effect.

\subsubsection{Water years 1975-1976 (early phases of development)}

In the first condition (status quo), precipitation-streamflow data pairs were selected when precipitation was recorded. In the second condition, two criteria were established to exclude the dry periods. (1) Following a long dry period (e.g., a week), rainfall needs to last at least two days, so that rainfall on the first day is able to increase the soil moisture. If the flow is greater than the base flow on the second day, the second day's precipitation-streamflow data pair becomes eligible. (2) The first day precipitation-streamflow data pair is also acceptable, if flow on the first day is already greater than the base flow when a rainfall event occurs on the first day.

\subsubsection{Water years 2000-2002 (later phases of development)}

Likewise, the first condition (status quo) included precipitation-streamflow data pairs if precipitation was recorded. The second condition excluded data pairs influenced by the lake/reservoir detention effect. If one of the following three criteria is met, the lake or the reservoir is regarded to have reached its maximum storage capacity, and excessive runoff resulted from subsequent rainfall. (1) Precipitation from the first day must be at least $41.7 \mathrm{~mm}$ to fill the lake or $31.5 \mathrm{~mm}$ to fill the reservoir. (2) It is acceptable if the sum of rainfall depths from several consecutive days reaches the specified depths, but flow values during these days must be consistently greater than the base flow value. (3) It is also acceptable if the first-day precipitation is less than the required precipitation, but the flow is greater than the base flow. This indicates the watershed is experiencing a wet period before this rainfall event.

\section{Analysis}

\subsection{Impervious area}

In land use planning, three methods are generally used to capture the impervious surface area of development: (1) use parcel data to quantify the impervious area (Alley and Veenhuis, 1983; Rogers and DeFee, 2005), (2) classify Landsat remote sensing imagery to extract the impervious area (Alberti et al., 2007; Shandas and Alberti, 2009), and (3) digitize high-resolution aerial photographs to delineate the impervious area (Light, 1993; Jennings and Jarnagin, 2002).

This study used the first method to calculate the impervious area from 1972 to 2002 using the Geographic Information System (GIS). GIS parcel data provide the parcel boundary and location, parcel area, building type, year built, and building square footage. Sorting these data by year built provides the state of development in the watershed each year. Road surface area was estimated by multiplying the road length with the average width of the roads in the watershed (Rogers and DeFee, 2005). Another component of impervious areas is the sidewalk. A majority of the development has sidewalks on both sides of the road. Hence, the road length was doubled as the sidewalk length. The sidewalk area was then estimated by multiplying the length with the average width of sidewalk.

Finally, estimation was made for the driveway impervious area. Previous studies have used the number of garage stalls multiplied by the average width ( $3 \mathrm{~m}$ ) of the driveway (Stone, 2004; Stone and Bullen, 2006). However, parcel data for The Woodlands do not provide driveway information. As frontyard setback distance was specified by The Woodlands Residential Development Standards: "a garage or garage addition must be set back at least 16 feet $(4.88 \mathrm{~m})$ from the side property line" (Community Associations of The Woodlands, 1996, Section 2.1, p. 14), this setback distance was multiplied by the width of a two-stall garage $(6 \mathrm{~m})$ to approximate the driveway impervious area, calculated by Eq. (3):

$$
\text { Driveway area }\left(\mathrm{m}^{2}\right)=\text { front-yard setback }(\mathrm{m}) \times 3 m
$$$$
\times \text { number of garage stalls }
$$

This driveway area was multiplied by the total number of parcels in the watershed to estimate the total driveway areas.

\subsection{Watershed runoff volume}

Annual mean runoff depth was calculated for the five water years. Watershed runoff depth $(\mathrm{m})$ is calculated by dividing the total runoff volume $\left(\mathrm{m}^{3}\right)$ by the watershed area $\left(\mathrm{m}^{2}\right)$. This method assumes a uniform depth of water falling onto the watershed. In this way, the flow volume is standardized and becomes comparable. The runoff depth was calculated using Eq. (4):

$H=\frac{Q_{i} \times t}{A}$

where $H$ is the watershed annual runoff depth $(\mathrm{m}) ; Q_{i}$ is the annual mean flow at year $i\left(\mathrm{~m}^{3} \mathrm{~s}^{-1}\right) ; t$ is a constant, $31,536,000 \mathrm{~s}$, the total number of seconds in a year; and $A\left(\mathrm{~m}^{2}\right)$ is the watershed area.

\subsection{Streamflow response}

A daily streamflow response value was created for streamflowprecipitation data pairs when precipitation was recorded (Jennings and Jarnagin, 2002). The streamflow response $\left(\mathrm{m}^{3} \mathrm{~s}^{-1} \mathrm{~m}^{-1}\right)$ value is calculated by diving mean daily streamflow $\left(\mathrm{m}^{3} \mathrm{~s}^{-1}\right)$ by daily precipitation ( $\mathrm{m}$ ). "Streamflow response value allows for a unified term for the data pair in which changes in streamflow as a result of variations in precipitation could be comparable for historical data" (Jennings and Jarnagin, 2002, p. 476). The average annual streamflow response value was calculated for each water year.

\subsection{Precipitation-streamflow correlation}

Three sets of correlation analyses were conducted to reflect the watershed characteristics using different drainage systems. The first set of correlation analysis provided an overall comparison of the two watersheds. For water years 1975-1976, correlation analysis was conducted for the watershed status quo condition and the condition in which the dry periods were excluded. For water years 2000-2002, the function of large stormwater detention facilities was assessed.

The second set of correlation analysis was conducted only for water years 2000-2002. The purpose was to compare the flood mitigation effectiveness of different drainage systems together with 
large stormwater detention facilities. Correlation analysis was conducted on a daily basis for precipitation-streamflow data pairs if precipitation $>0 \mathrm{~mm}$. Precipitation data were further grouped into two categories: $>0 \mathrm{~mm}$ and $>6 \mathrm{~mm}$. The first category $(>0 \mathrm{~mm})$ stands for all rainfall events. The second category $(>6 \mathrm{~mm}$ ) includes moderate and large rainfall events (Jennings and Jarnagin, 2002).

The third set of correlation analysis was also conducted only for water years 2000-2002. It aimed at evaluating flood mitigation effectiveness solely from different drainage systems. Finally, correlation analysis evaluated the daily precipitation-streamflow relationship and the relationship between yesterday's precipitation and today's streamflow (Rogers and DeFee, 2005).

It was found that in water years 2000-2002, Watershed \#1 streamflow sometimes did not reach the highest value on the same day as when a large rainfall occurred. A peak flow emerged on the second day. However, this phenomenon was less frequently observed in Watershed \#2 in this period. This is perhaps because Watershed \#1's open drainage system detained runoff and presented a lag time after rainfall, whereas Watershed \#2's conventional drainage system discharged runoff efficiently without detaining it.

\section{Results}

\subsection{Impervious area}

Development conditions in Watershed \#1 and Watershed \#2 are presented in Fig. 6. By the end of 2002, there were 355 ha (877acres) of impervious area in Watershed \#1 and 743 ha (1835 acres) in Watershed \#2. These areas accounted for $15 \%$ and $11 \%$ of Watershed \#1 and Watershed \#2 areas, respectively. It is important to note that Watershed \#1 contains 93 ha (203acres) of The Woodlands Town Center commercial area. This commercial area presents a high percentage of impervious cover and will adversely impact the effectiveness of the open drainage system.

\subsection{Watershed runoff volume}

The annual runoff depths of five specific water years are shown in Fig. 7. Two trends emerged in this analysis. The first trend was that Watershed \#1 has a lower runoff depth than Watershed \#2 in each year examined-meaning less runoff volume has been generated from Watershed \#1. The second trend was that a noteworthy increase in runoff depth occurred in Watershed \#2 in the later phases of development. In the early phases (1975-1976), Watershed \#2's runoff depths were around three times those of Watershed \#1. However, in the later phases (2000-2002), these ratios increased to five to eight times.

Because Watershed \#2 has a lower percentage of impervious area than Watershed \#1, more runoff volume from Watershed

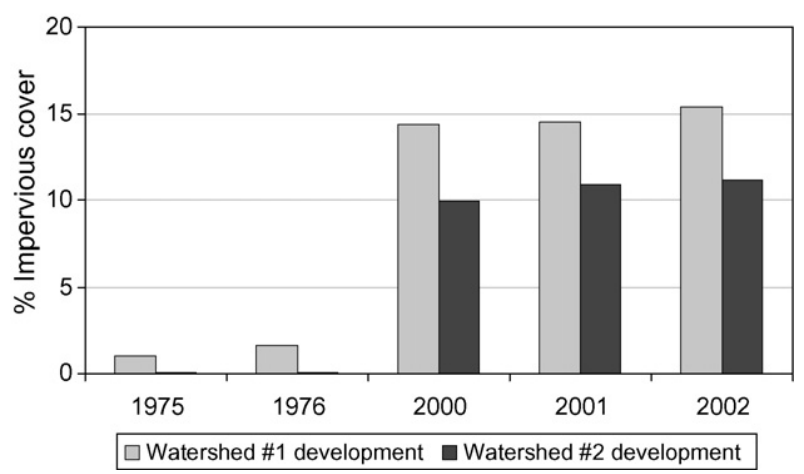

Fig. 6. Cumulated percentage of impervious area in Watershed \#1 (open drainage) and Watershed \#2 (conventional drainage).

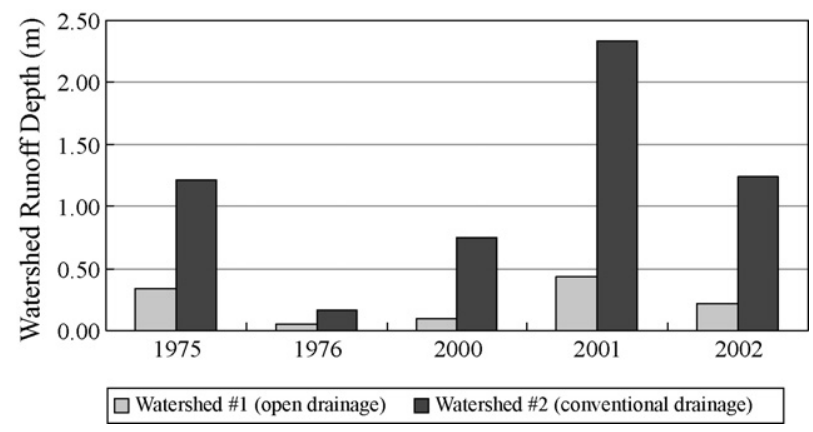

Fig. 7. Surface runoff depths of Watershed \#1 (open drainage) and Watershed \#2 (conventional drainage).

\#2 could be attributed to the differences in drainage designs. In Watershed \#1, the open drainage system and The Woodlands Lake detained a large amount of water for infiltration and evapotranspiration. Conversely, in Watershed \#2, the pipe drainage system facilitates runoff without detaining it-counteracting the detention function provided by the Bear Branch Reservoir.

\subsection{Streamflow response}

Fig. 8 shows the streamflow response values and the annual precipitation in the two watersheds. Precipitation values were similar in the two watersheds in each year examined. However, the streamflow response values presented differences in the later phases of development. Likewise, two trends emerged in this analysis. The first trend was that the streamflow response values remained low in the early phases in both watersheds. The second trend was that the value increased at a much greater rate in Watershed \#2 than in Watershed \#1 in the later phases.

In 2002, the Watershed \#2 streamflow response value was more than nine times that of Watershed \#1-indicating more flashy streamflow after development. Given the fact that Watershed \#2 has less percentage of impervious area than Watershed \#1, thus the conventional drainage system has altered Watershed \#2 to be more sensitive in response to rainfall than Watershed \#1.

\subsection{Precipitation-streamflow correlation analysis}

Four sets of correlation analyses were conducted and the results are presented in Tables 4-6. The first set of precipitation-streamflow correlation analysis was conducted on a daily basis, and Pearson's correlation coefficients $(r)$ are summarized in Table 4 . In the early phases, when both watersheds maintained forest conditions, streamflow and precipitation showed little correlation-low $r$ values. Also, there was little variation in correlation between the dry and wet periods.

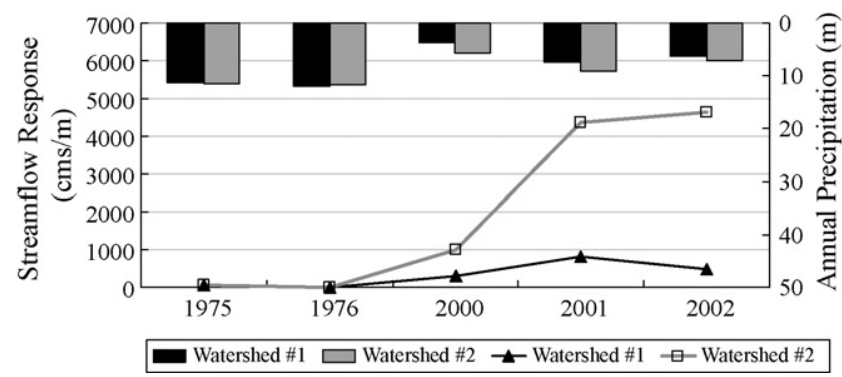

Fig. 8. Annual precipitation ( $\mathrm{m})$ and streamflow response value $\left(\mathrm{m}^{3} \mathrm{~s}^{-1} \mathrm{~m}^{-1}\right)$ of Watershed \#1 (open drainage) and Watershed \#2 (conventional drainage). 
Table 4

Correlation analysis of precipitation ( $>0 \mathrm{~mm}$ ) and daily mean streamflow. ${ }^{\mathrm{a}}$.

\begin{tabular}{|c|c|c|c|}
\hline \multirow[t]{2}{*}{ Water year } & \multirow[t]{2}{*}{ Watershed } & \multicolumn{2}{|c|}{ Precipitation (>0 mm) } \\
\hline & & $\begin{array}{l}\text { Correlation } \\
\text { coefficient }^{\mathrm{b}}\end{array}$ & $\begin{array}{l}\text { Sample } \\
\text { number }\end{array}$ \\
\hline 1975-1976 & $\# 1$ & 0.35 & 193 \\
\hline $\begin{array}{l}\text { Before excluding } \\
\text { dry periods }\end{array}$ & $\# 2$ & 0.26 & 209 \\
\hline 1975-1976 & $\# 1$ & 0.35 & 158 \\
\hline $\begin{array}{l}\text { After excluding } \\
\text { dry periods }\end{array}$ & \#2 & 0.39 & 116 \\
\hline $2000-2002$ & $\# 1$ & 0.17 & 379 \\
\hline $\begin{array}{l}\text { Before excluding } \\
\text { lake detention } \\
\text { effect }\end{array}$ & \#2 & 0.48 & 483 \\
\hline 2000-2002 & $\# 1$ & 0.10 & 43 \\
\hline $\begin{array}{l}\text { After excluding } \\
\text { lake detention } \\
\text { effect }\end{array}$ & \#2 & 0.61 & 90 \\
\hline
\end{tabular}

In the later phases, the correlation remained low in Watershed \#1 but increased to be much higher in Watershed \#2. Hence, Watershed \#1 stormwater management strategies seemed to be more effective than those of Watershed \#2 in mitigating flood. In other words, the open drainage system together with The Woodlands Lake detained water more effectively than did the conventional drainage system and the Bear Branch Reservoir combined. The lake and the reservoir performed a similar detention function. However, the conventional drainage system adversely offset the reservoir's detention effect. After The Woodlands Lake detention effect was excluded, low precipitation-streamflow correlation was still observed in Watershed \#1. The open drainage system alone suggested a viable stormwater detention solution.

The second set of analysis included yearly analysis and rainfall intensity categorical analysis, and the correlation coefficients $(r)$ are listed in Table 5 . This set of analysis was conducted only for water years 2000-2002. As aforementioned, precipitationstreamflow data pairs were further divided into two categories based on precipitation values $>0 \mathrm{~mm}$ and $>6 \mathrm{~mm}$. Similar to Table 4 results, Watershed \#1 responded to rainfall in a manner similar to its predevelopment forest condition (low $r$ values). Conversely, Watershed \#2 presented high precipitation-streamflow correlations during 2000-2002 when the conventional drainage system was installed (high $r$ values).

The third set of correlation analysis was also conducted only for water years 2000-2002, and the correlation coefficients $(r)$ are listed in Table 6. This set of analysis aimed at evaluating the flood mitigation effectiveness solely provided by drainage systems. In this analysis, soil was saturated and the detention effects of The Woodlands Lake and the Bear Branch Reservoir were excluded.

Two models were used: the daily model and the simplified lagged model. In the daily model, Watershed \#2 showed a higher precipitation-streamflow correlation than Watershed \#1 for both rainfall intensities examined, indicating a situation vulnerable to flooding. In contrast, Watershed \#1 showed little precipitation-streamflow correlation, suggesting that the open drainage system was effective in detaining runoff.

Table 5

Correlation analysis of precipitation and streamflow before excluding lake/reservoir detention effect. ${ }^{\mathrm{a}}$.

\begin{tabular}{|c|c|c|c|c|c|}
\hline \multirow[t]{3}{*}{ Water year } & \multirow[t]{3}{*}{ Watershed } & \multicolumn{4}{|l|}{ Precipitation } \\
\hline & & \multicolumn{2}{|l|}{$>0 \mathrm{~mm}$} & \multicolumn{2}{|l|}{$>6 \mathrm{~mm}$} \\
\hline & & Correlation coefficient ${ }^{\mathrm{b}}$ & Sample number & Correlation coefficient $^{\mathrm{b}}$ & Sample number \\
\hline \multirow[t]{2}{*}{2000} & $\# 1$ & 0.03 & 98 & 0.06 & 19 \\
\hline & \#2 & 0.69 & 134 & 0.67 & 36 \\
\hline \multirow[t]{2}{*}{2001} & $\# 1$ & 0.03 & 161 & 0.03 & 47 \\
\hline & \#2 & 0.36 & 191 & 0.24 & 68 \\
\hline \multirow[t]{2}{*}{2002} & \#1 & 0.42 & 120 & 0.38 & 31 \\
\hline & $\# 2$ & 0.54 & 156 & 0.55 & 53 \\
\hline
\end{tabular}

a Hurricane Allison on 6/9/2001 was excluded as an outlier.

b Correlation coefficient: Pearson's coefficient " $r$ ".

Table 6

Correlation analysis of precipitation and streamflow after excluding the lake/reservoir detention effect. ${ }^{\mathrm{a}}$

\begin{tabular}{|c|c|c|c|c|c|}
\hline \multirow[t]{3}{*}{ Model } & \multirow[t]{3}{*}{ Watershed } & \multicolumn{4}{|l|}{ Precipitation } \\
\hline & & \multicolumn{2}{|l|}{$>0 \mathrm{~mm}$} & \multicolumn{2}{|l|}{$>6 \mathrm{~mm}$} \\
\hline & & Correlation coefficient ${ }^{\mathrm{b}}$ & Sample number & Correlation coefficient ${ }^{\mathrm{b}}$ & Sample number \\
\hline \multicolumn{6}{|l|}{ Daily model ${ }^{\mathrm{C}}$} \\
\hline \multirow[t]{2}{*}{ Mean flow } & $\# 1$ & 0.11 & 43 & 0.32 & 25 \\
\hline & \#2 & 0.61 & 90 & 0.52 & 65 \\
\hline \multirow[t]{2}{*}{ Max. flow } & $\# 1$ & 0.07 & 43 & 0.17 & 25 \\
\hline & \#2 & 0.62 & 90 & 0.55 & 65 \\
\hline \multicolumn{6}{|l|}{ Lagged model $^{\mathrm{d}}$} \\
\hline \multirow[t]{2}{*}{ Mean flow } & \#1 & 0.42 & 16 & 0.30 & 11 \\
\hline & \#2 & 0.29 & 44 & 0.20 & 36 \\
\hline \multirow[t]{2}{*}{ Max. flow } & $\# 1$ & 0.55 & 16 & 0.48 & 11 \\
\hline & \#2 & 0.21 & 44 & 0.14 & 36 \\
\hline
\end{tabular}

a Hurricane Allison on 6/9/2001 was excluded as an outlier.

b Correlation coefficient: Pearson's coefficient " $r$ ".

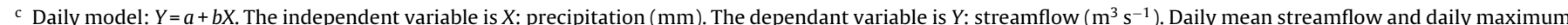
streamflow were used as the dependant variable $Y$.

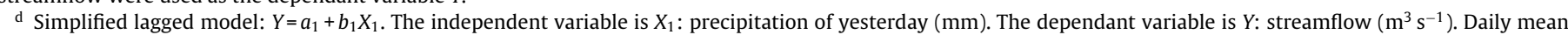
streamflow and daily maximum streamflow were used as the dependant variable $Y$. 

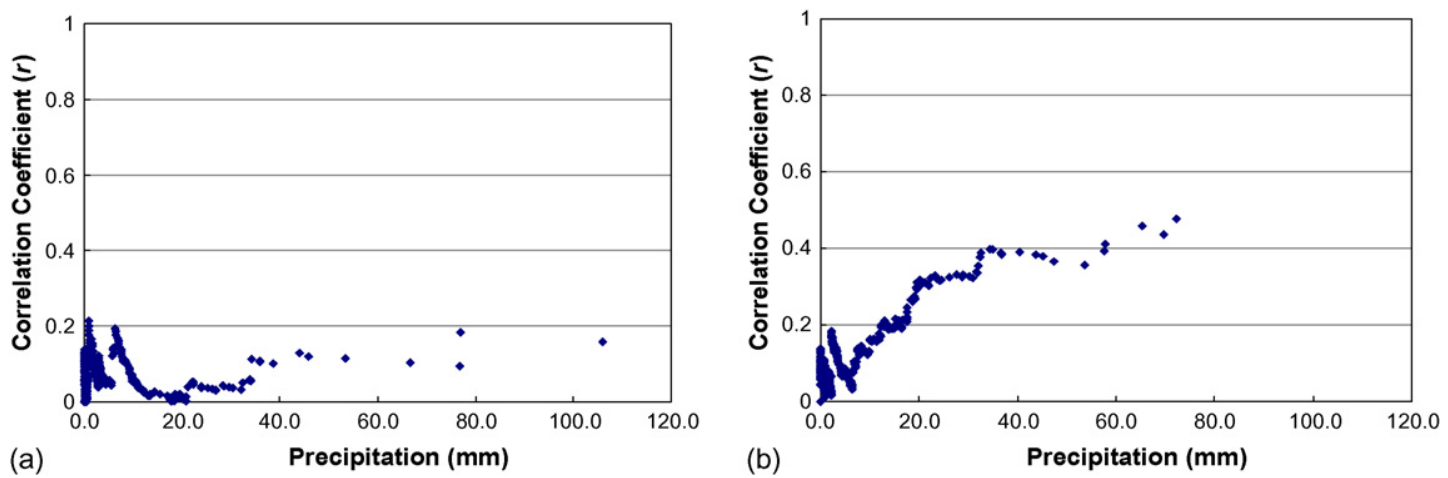

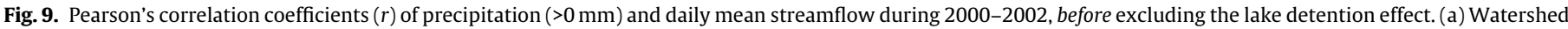
\#1 (open drainage), (b) Watershed \#2 (conventional drainage).

The simplified lagged model further demonstrated the lagtime effect, since the slope and the flow path length are similar in the two watersheds. In this model, Watershed \#1 showed a higher precipitation-streamflow correlation than Watershed \#2. This means peak flow was less likely to occur on the same day as when a large rainfall emerged in Watershed \#1. In Watershed \#1, yesterday's precipitation was a better predictor than today's precipitation for today's streamflow. In Watershed \#2, however, yesterday's precipitation and today's streamflow showed little correlation. This means that Watershed \#2 discharged runoff faster than Watershed \#1 instead of detaining it. This set of analysis showed that when the detention effect of the lake/reservoir was excluded, the open drainage system presented an advantage over the conventional drainage system in mitigating flood.

The fourth set of analysis enumerated precipitation-streamflow correlation coefficients $(r)$ as precipitation increases. It provided a comprehensive correlation analysis for all the precipitation-streamflow data pairs. This analysis demonstrated the incremental change of the correlation and minimized the potential bias due to the precipitation intensity thresholds specified (e.g., precipitation $>6 \mathrm{~mm}$ indicates a large rainfall).

Figs. 9 and 10 present the scatterplots obtained from the daily model. Fig. 9 showed that before excluding the lake detention effect, $r$ values remained low, near zero, in Watershed \#1, regardless of the precipitation intensities. In Watershed \#2, it was evident that $r$ values increased as precipitation increased. Fig. 10 showed a similar trend; that is, after excluding the lake detention effect, $r$ values remained low in Watershed \#1, but the values increased in Watershed \#2 as rainfall intensity increased. Also, comparing conditions before and after excluding the lake detention effect, the correlation became much higher in Fig. 10 than in Fig. 9, particularly during a large rainfall.
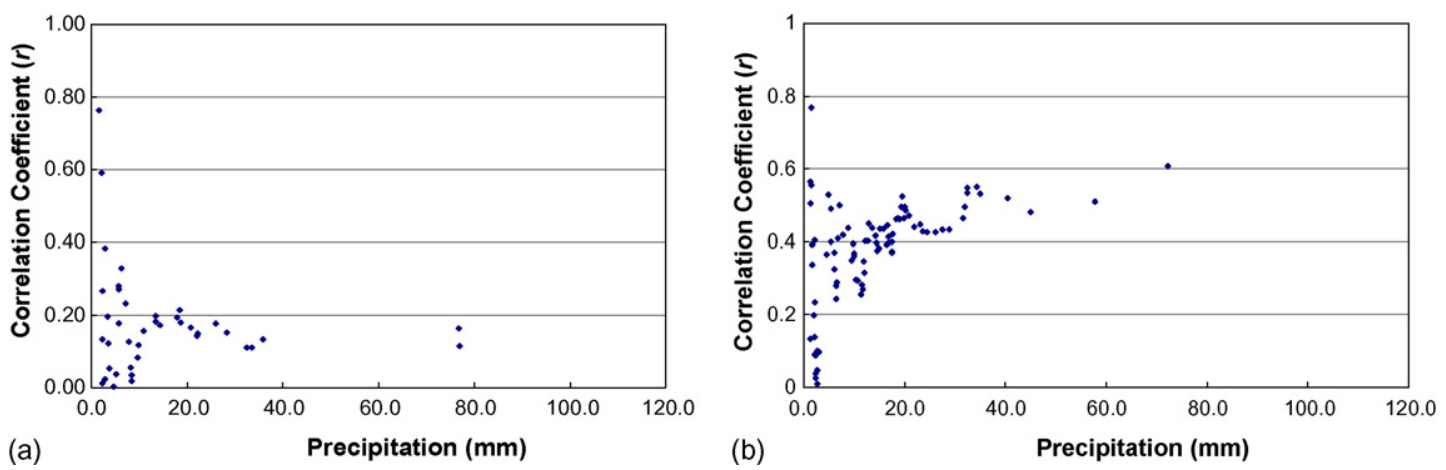

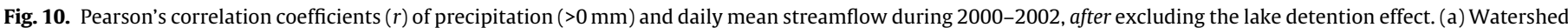
\#1 (open drainage), (b) Watershed \#2 (conventional drainage).

\section{Discussion}

The open drainage system can detain stormwater runoff for infiltration in addition to its drainage function, whereas the conventional drainage system aims at passing runoff down$26 \%$ runoff volume increase in Watershed \#1 (open drainage). However, a much greater increase, $110 \%$, was found in Watershed \#2 (conventional drainage). Land with high permeable soils (e.g., sandy soils) accounted for $49 \%$ of Watershed \#1 area and $35 \%$ of Watershed \#2 area, and by 2002 , impervious areas accounted for $15 \%$ and $11 \%$ of Watershed \#1 and Watershed \#2 areas, respectively. Intuitively, these differences are not significant enough to engender such a vast difference in runoff $(26 \%$ versus $110 \%$ ). Thus, the difference in runoff volume could be largely attributed to the difference between drainage designs. Compared with conventional drainage, open drainage enabled more water to infiltrate and evaporate before discharging downstream.

Streamflow response analysis further illustrated that the conventional drainage watershed presented a high runoff increase per unit of precipitation. Obviously the conventional drainage system has exerted a much greater impact on the natural flow regime than the open drainage watershed. Natural streams became flashy channels in the conventional drainage watershed and suggested a condition prone to flooding. In contrast, in the open drainage watershed, streamflow peaks occurred with a longer lag time than in the conventional drainage watershed. The open drainage watershed responded to rainfall in a manner similar to its forest conditions, in which streamflow did not necessarily increase when it rained. Although the Bear Branch Reservoir helped detain runoff in the conventional drainage watershed, the conventional drainage system stream as fast as possible. After development, there was a 
efficiently conveyed runoff downstream and muted the detention effect of the reservoir.

Moreover, the yearly correlation analysis showed that the combined effect of the open drainage system and The Woodlands Lake was consistently more effective in detaining water than the conventional drainage system combined with the Bear Branch Reservoir. The Woodlands Lake (92 ha) and the Bear Branch Reservoir (21 ha) were designed as flood control devices (U.S. Army Corps of Engineers, 1982). After excluding the lake/reservoir detention effect, a much higher precipitation-streamflow correlation emerged in the conventional drainage watershed, showing the positive flood mitigation function the reservoir could provide and the negative impacts on this function the conventional drainage system could cause. The Woodlands Lake has played an important role in detaining runoff in the open drainage watershed. But even without the lake, the open drainage system maintained a low precipitation-streamflow correlation. Moreover, the lagged model showed the elongated lag time this drainage system could bring.

Prior to the construction of The Woodlands Lake (1985), The Woodlands survived storm in excess of 100-year levels in 1979 with little property damage (Girling and Kellett, 2005). Although not based on scientific study, it was believed that the open drainage system played a vital role in protecting The Woodlands in this significant event (Morgan and King, 1987; Galatas and Barlow, 2004). Some other storms also help explain the effectiveness of this open drainage system. On September 28, 1987, southern Montgomery County experienced a $130-\mathrm{mm}$ rain. High water and flooding were reported along Panther Creek. The city of Oak Ridge North to the east of The Woodlands and Timber Ridge subdivisions to the south of The Woodlands were flooded. In contrast, no flooding was observed in The Woodlands (NOAA, 1987). In 1994, a 500-year level storm occurred in The Woodlands, with over $890 \mathrm{~mm}$ of rain falling within $36 \mathrm{~h}$. Again, the open drainage system successfully endured this significant event (Galatas and Barlow, 2004).

After The Woodlands took a different approach in drainage design, especially after its ownership was changed in 1997, homeowners started to complain about the flooded streets during large storms (Haut, 2006). On April 2, 2000, The Woodlands had considerable street flooding and many roads became impassable (NOAA, 2000). Again in the 2008 Hurricane Ike, a large territory of The Woodlands was flooded. The western Woodlands, developed with the conventional drainage system, was severely flooded. A number of streets and thoroughfares became impassable after the hurricane (Madere, 2008).

The study also provided some suggestions for planning and design practices. Two issues emerged. The first issue is that location is an important design consideration of developing surface drainage (USEPA, 1999; Villarreal et al., 2004). Open drainage channels in The Woodlands were designed in conjunction with circulation systems, soil characteristics, and site drainage patterns. Check dams were integrated with grading plans to ensure maximum infiltration and groundwater recharge (WMRT, 1973a, 1973c). The second issue is that the combined effect of several BMPs is better than that of a stand-alone BMP (USEPA, 1999). This study showed that open drainage swales could be used as a stand-alone BMP but are more effective if used together with large detention facilities. Also, open drainage swales in The Woodlands demonstrated effectiveness in detaining runoff during large storms, and this finding contributed to the USEPA swale design guidelines.

Nevertheless, the research design could not address several confounding factors and presented some limitations. One of the limitations was the Thiessen polygon method used for estimating precipitation. The Thiessen method assumes uniform rainfall within delineated polygons. However, there were cases when flow values increased enormously while no precipitation records were shown. Because of the localized rainfall pattern in Texas, it is possible that a rain occurred within a watershed but was not captured by its nearest weather station. Due to the limitation of the Thiessen polygon method, there are inconsistency in the results of streamflow response analysis and precipitation-streamflow correlation analysis.

Another limitation was the difficulty of fully capturing the impervious area in the watershed. The sum area of building footprints, roads, sidewalks, and driveways provided an approximation of the impervious surface. In this regard, the available data meant to show the general trend of development. Some other components of impervious cover were obscured in the analysis (e.g., parking lot, tot lot playground, and various other pavement areas).

Finally, using watershed as a unit of analysis made it difficulty to delineate watersheds that were ideal for the scope of study. On one hand, Watershed \#1 includes a large portion of The Woodlands Town Center, a commercial area with large impervious areas. The Town Center shall undermine the effectiveness of the open drainage system demonstrated in the results. On the other hand, Watershed \#1 contains less than one third of the Village of Grogan's Mill, the only village that strictly used McHarg's open drainage design. In short, the effectiveness of the open drainage system was not fully illustrated due to limitations of the research design.

\section{Conclusions}

This study evaluates the ecological engineering principles used in drainage designs in The Woodlands new town development. This study provides evidence that the open drainage system effectively mitigates floods while conventional one does not. The open drainage system generates less runoff volume and increases the lag time to reach peak flow. Therefore, the open drainage system presents a viable alternative to the conventional drainage system in urban development, particularly in the Houston area, where annual hurricane generates intense precipitation in short durations. Although clay soil will hinder stormwater infiltration, the open drainage swale provides greater storage than the curb-andgutter drainage system. Moreover, the meandering shape of swales elongates the time for runoff to reach streams.

McHarg's open drainage design mimics the natural hydrologic cycle so that the impact of urban development on the watershed could be minimized. This innovation, however, did not come easily. Cultural preferences sometimes transcend the ecological benefits in the design decision-making process. Such has been the case in The Woodlands when the open drainage system was changed to the conventional drainage one because of its lack of popularity among homeowners (Kutchin, 1998; Galatas and Barlow, 2004). The well-protected pine forest may give homeowners and visitors an impression that this town is developed in harmony with nature, but the less visible ecological values that open drainage could bring are often beyond what the general public could comprehend. It takes time for the general public to value and appreciate the ecological design innovations.

This study also suggests that large detention facilities, such as The Woodlands Lake and the Bear Branch Reservoir, present an effective stormwater management strategy. In addition, using a combination of several BMPs (e.g., open drainage system and The Woodlands Lake) is a better strategy. Also, the location of the open drainage channels and the detention facilities present important planning and design considerations. McHarg placed the open drainage channels where high permeable soils were available for stormwater infiltration. The Woodlands Lake and the Bear Branch Reservoir were also strategically located to collect runoff from different drainage zones. Future study shall investigate how watersheds respond during single intense storms and whether the 
general public's perception on open surface drainage change over time.

\section{References}

Alberti, M., Booth, D., Hill, K., Coburn, B., Avolio, C., Coe, S., Spirandelli, D., 2007. The impact of urban patterns on aquatic ecosystems: an empirical analysis in Puget lowland sub-basins. Landscape Urban Plan. 80 (4), 345-361.

Alley, W.M., Veenhuis, J.E., 1983. Effective impervious area in urban runoff modeling. J. Hydraul. Eng. 109, 313-319.

Arnold, C.L., Gibbons, C.J., 1996. Impervious surface coverage - the emergence of a key environmental indicator. J. Am. Plann. Assoc. 62 (2), 243-258.

Bergen, S.D., Bolton, S.M., Fridley, J.L., 2001. Design principles for ecological engineering. Ecol. Eng. 18, 201-210.

Booth, D.B., Jackson, C.R., 1997. Urbanization of aquatic systems: degradation thresholds, stormwater detection, and the limits of mitigation. J. Am. Water Resour. As. 33 (5), 1077-1090.

Brabec, E., 2009. Imperviousness and land use policy: toward an effective approach to watershed planning. J. Hydrol. Eng. 14 (4), 425-433.

Brander, K.E., Owen, K.E., Potter, K.W., 2004. Modeled impacts of development type on runoff volume and infiltration performance. J. Am. Water Resour. As. 40 (4), 961-969.

Chaubey, I., Edwards, D.R., Daniel, T.C., Moore Jr., P.A., Nichols, D.J., 1994. Effectiveness of vegetative filter strips in retaining surface-applied swine manure constituents. Trans. ASAE 37, 845-850.

Community Associations of The Woodlands, TX, 1996. Residential development standards.

Ellis, J.B., Marsalek, J., 1996. Overview of urban drainage: environmental impacts and concerns, means of mitigation and implementation policies. J. Hydraul. Res. 34 (6), 723-731.

Ferguson, B.K., 1998. Introduction to Stormwater. John Wiley and Sons, New York.

Galatas, R., Barlow, J., 2004. The Woodlands: The Inside Story of Creating a Better Hometown. Urban Land Institute, Washington, DC.

Gattie, D.K., Smith, M.C., Tollner, E.W., McCutcheon, S.C., 2003. The emergence of ecological engineering as a discipline. Ecol. Eng. 5, 409-420.

Gause, J.A., Garvin, A., Kellenberg, S.R., 2002. Great Planned Communities. Urban Land Institute, Washington, DC.

Girling, C., Kellett, R., 2002. Comparing stormwater impacts and costs on three neighborhood plan types. Landscape J. 21, 100-109.

Girling, C., Kellett, R., 2005. Skinny Streets and Green Neighborhoods: Design for Environment and Community. Island Press, Washington, DC.

Haut, R., 2006. Environmental action plan: The Woodlands, Texas. Retrieved from: http://files.harc.edu/Documents/Announcements/2007/WoodandsEnvironmen talActinPlan.pdf.

Horner, R., Lim, H., Burges, S.J., 2002. Hydrologic monitoring of the Seattle ultraurban stormwater management projects. In: Water Resources Series Technical Report F (No. 170). University of Washington, Seattle.

Jennings, D.B., Jarnagin, S.T., 2002. Changes in anthropogenic impervious surfaces, precipitation and daily streamflow discharge: a historical perspective in a midAtlantic subwatershed. Landscape Ecol. 17, 471-489.

Kim, J., Ellis, C.D., 2009. Determining the effects of local development regulations on landscape structure: Comparison of The Woodlands and North Houston, TX Landscape Urban Plan. 92, 293-303.

Kutchin, J., 1998. How Mitchell Energy \& Development Corp. Got Its Start and How It Grew. Mitchell Energy \& Development Corporation, The Woodlands, Texas.

Light, D.K., 1993. The national aerial photography program as a geographic information system resource. Photogramm. Eng. Rem. S. 59, 61-65.

Madere, M., 2008. Tropical weather: The Woodlands archives (Houston Chronicle). Retrieved from: http://blogs.chron.com/hurricanes/the_woodlands/.

Matlock, M.D., Osborn, G.S., Hession, W.C., Kenimer, A.L., Storm, D.E., 2001. Ecological engineering: a rationale for standardized curriculum and professional certification in the United States. Ecol. Eng. 17, 403-409.

McHarg, 2006. The Essential Ian McHarg: Writing on Design and Nature. Island Press, Washington, DC.

McHarg, I.L., 1969. Design with Nature. Doubleday/Natural History Press, New York.

McHarg, I.L., Steiner, F.R. (Eds.), 1998. To Heal the Earth: Selected Writings of Ian L. McHarg. Island Press, Washington, DC.

McHarg, I.L., Sutton, J., 1975. Ecological plumbing for the Texas coastal plain: the Woodlands new town experiment. Landscape Archit. 65 (1), 80-90.

Mitsch, W., Jørgensen, S., 1989. Ecological Engineering: An Introduction to Ecotechnology. Wiley, New York.

Mitsch, W.J., Jørgensen, S.E., 2003. Ecological engineering: a field whose time has come. Ecol. Eng. 20, 363-377.

Morgan, G., King, J., 1987. The Woodlands: New Community Development 1964-1983. Texas A\&M University Press, TX.

National Climatic Data Center (NCDC). Retrieved from: http://www.ncdc.noaa.gov.

National Oceanic and Atmospheric Administration (NOAA), 2000. National Weather Service Storm Data and Unusual Weather Phenomena. Retrieved from: www.srh.noaa.gov/hgx/severe/2000/apr00hgx.pdf.

National Oceanic and Atmospheric Administration (NOAA), National Weather Service Forecast Office, 1987. Some Recent September Severe Weather Highlights for Southeast Texas. Retrieved from: http://www.srh.noaa.gov/hgx/ severe/events/september.htm.
Ndubisi, F., 2002. Ecological Planning: A Historical and Comparative Synthesis. Johns Hopkins University Press, Baltimore.

Ndubisi, F., 2008. Sustainable regionalism: evolutionary framework and prospects for managing metropolitan landscapes. Landscape J. 27 (1), 51-68.

Odum, H.T., 1994. Ecological engineering: the necessary use of self-design. J. Environ. Eng. 120 (3), 486-489.

Paul, M.J., Meyer, J.L., 2001. Streams in the urban landscape. Annu. Rev. Ecol. Syst 32, 333-365.

Prince George's County, Department of Environmental Resources, 1999. Low-Impact Development Design Strategies: An Integrated Design Approach. Department of Environmental Resources, Programs and Planning Division.

Rogers, G.O., DeFee, B.B., 2005. Long-term impact of development on a watershed: early indicators of future problems. Landscape Urban Plan. 73, 215-233.

Schmitt, T.J., Dosskey, M.G., Hoagland, K.D., 1999. Filter strip performance and processes for different vegetation, widths, and contaminants. J. Environ. Qual. 28, 1479-1489.

Schueler, T.R., 1994. The importance of imperviousness. Watershed Protection Techniques $1,100-111$

Shandas, V., Alberti, M., 2009. Exploring the role of vegetation fragmentation on aquatic conditions: linking upland with riparian areas in Puget Sound lowland streams. Landscape Urban Plan. 90, 66-75.

Spirn, A.W., 1984. The Granite Garden: Urban Nature and Human Design. Basic Books, New York.

Steiner, F., 2008. The Living Landscapes: An Ecological Approach to Landscape Planning. Island Press, Washington, DC.

Steiner, F.R., Osterman, D.A., 1998. Landscape planning: a working method applied to a case study of soil conservation. Landscape Ecol. 1 (4), 213-226.

Stone, B., Bullen, J.L., 2006. Urban form and watershed management: how zoning influences residential stormwater volumes. Environ. Plann. B 33, 21-37.

Stone, B., 2004. Paving over paradise: how land use regulations promote residentia imperviousness. Landscape Urban Plan. 69, 101-113.

Texas Natural Resources Information System (TNRIS). Available from: http://www.tnris.state.tx.us/.

Todd, J., Brown, E.J.G., Wells, E., 2003. Ecological design applied. Ecol. Eng. 20 421-440.

U.S. Army Corps of Engineers, 1982. A permit to place fill material associated with the construction of two water retention structures and perform channel modifications in Spring Creek, in Bear Branch and Panther Branch tributaries at locations in Montgomery County, Texas. Permit number: 15336.

U.S. Geological Survey (USGS). Retrieved from: http://www.usgs.gov.

United States Environmental Protection Agency (USEPA), 1999. Storm Water Technology Fact Sheet: Vegetated Swales. United States Environmental Protection Agency, Office of Water. EPA 832-F-99-006.

Villarreal, E.L., Semadeni-Davies, A., Bengtsson, L., 2004. Inner city stormwater control using a combination of best management practices. Ecol. Eng. 22, 279-298.

Wallace, McHarg, Roberts, and Todd (WMRT), 1973a. Woodlands New Community: An Ecological Inventory. Wallace, McHarg, Roberts and Todd, Philadelphia.

Wallace, McHarg, Roberts, and Todd (WMRT), 1973b. Woodlands new community: Guidelines for site planning. Wallace, McHarg, Roberts and Todd, Philadelphia.

Wallace, McHarg, Roberts, and Todd (WMRT), 1973c. Woodlands New Community: Phase One: Land Planning and Design Principles. Wallace, McHarg, Roberts and Todd, Philadelphia.

Wallace, McHarg, Roberts, and Todd (WMRT), 1974. Woodlands New Community: An Ecological Plan. Wallace, McHarg, Roberts and Todd, Philadelphia.

Zipperer, W.C., Wu, J.G., Pouyat, R.V., Pickett, T., 2000. The application of ecologica principles to urban and urbanizing landscapes. Ecol. Appl. 10 (3), 685-688.

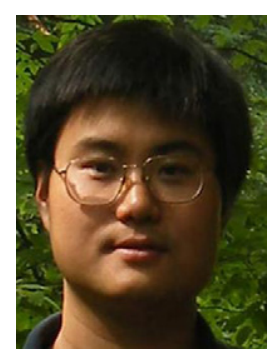

Bo Yang is an Assistant Professor in the Department of Landscape Architecture and Environmental Planning. Dr. Yang received his Ph.D. in Urban and Regional Science (2009) and Master of Landscape Architecture (2009) from Texas A\&M University, Master of Architecture (2004) and Bachelor of Architecture (2002) from Huazhong University of Science \& Technology in China. His areas of interest are environmental planning and technology, stormwater management, community planning and design, water related ordinances, and landscape history and theory in China and East Asia.

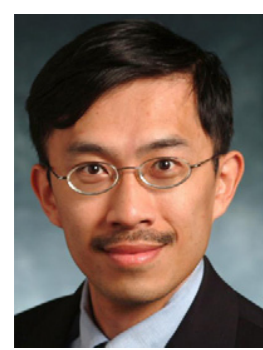

Ming-Han Li is an Associate Professor in the Department of Landscape Architecture and Urban Planning at Texas A\&M University. He is also an Associate Research Engineer with Texas Transportation Institute. Dr. Li received his Ph.D. in Urban and Regional Science (2002) and Master of Landscape Architecture (1998) from Texas A\&M University, M.S. in Civil Engineering from UT, Austin (1995) and B.S. in Agricultural Engineering from National Taiwan University (1990). His research experience is in stormwater management, bioretention, soil erosion control and roadside vegetation management. Dr. Li is a Professional Engineer and a registered Landscape Architect in Texas. 